Jurnal Psikologi Pendidikan \& Konseling

Volume 3 Number 2 December 2017. Page 23-29

p-ISSN: 2443-2202 e-ISSN: 2477-2518

Homepage: http://ojs.unm.ac.id/index.php/JPPK

\title{
The Meaning Of Divorce For Wives (The Marriage Age 20 Years And Above)
}

\author{
Eva Meizara Puspita Dewi \\ Pschology Departement, Universitas Negeri Makassar \\ Email: evabasti@yahoo.com
}

(diterima: 21-April-2017; direvisi: 05-December-2017; dipublikasikan: 27-Desember-2017)

\begin{abstract}
This study aims to (1) describe the overview of the life of the Marriage (2) Explain the reason for the wives did divorce at the age of marriage has reached 20 years (3) Knowing the psychological condition of the subjects post-divorce. This study uses a qualitative method of data collection in the form of interviews and documentation. The research subjects are four and add with the informant as much as four people. The results of this research are (1) Household life subjects had massive conflicts, domestic violence and even infidelity. The conflict that often occurs and the lack of ability to make problem solving the complex problems faced. Child's attitude does not affect the subject's decision to divorce. (2) A lot of unpleasant incident in the relationship of husband and wife for households. Subjects have been feeling tired and physically to survive, while there was no sign of positive change of her husband, the kids are great, economically ex-husband and the family is quite helpful and the subjects feel life itself will be better then the subject decided to divorce. Perception wife, honored to perform contested normal divorced from the talak divorce. (3) Subject to feel more calm because of the conflict intensity dropped dramatically after the divorce for no longer live at home with her husband. Subjects had a lot of time to themselves and deepen the use of religion and worship. Only in this way, the subject may continue to be grateful and do not regret the past life. However, the subjects had to make a living despite the additional subsidy granted by the former husband. In the social interaction is often the subject of conversation to be sensitive to neighbors or group those talks about divorce.
\end{abstract}

Keywords: Meaning of Divorce; Wife

Copyright (C) 2017 Universitas Negeri Makassar. This is an open access article under the CC BYNC-ND license (http://creativecommons.org/licenses/by-nc-nd/4.0/).

\section{INTRODUCTION}

Marriage is a necessity of life for all mankind, from ancient time up to the present. In marriage, there will be a relationship between husband and wife and then they can obtain offspring with the birth of children. The legitimate marriage aims to form a happy family both born and inner (Konoras and Sarkol, 2014).

When marriage takes place, whether marriage is first or second, almost everyone expects happiness and lasting marriage bonds.
However, because marriage demands adjustment to the demands of new roles and responsibilities of both partners, these hopes often run aground in the middle of the road and do not come true. This is because such self-adjustment is not an easy one for each couple. Especially for couples married at a young age, the inability to adapt to new roles and responsibilities often leads to conflict, and even ends in divorce (Papalia, 2008)

The age of marriage under five years is the age of adjusting the habits and personality of these two beings. In this phase, the struggle of 
the couple is very large because it begins to show the true personality, without any hint or mask so it is very easy and the potential for a bickering. If in this phase will determine the continuation of future marriages. If that does not work, then there will be a divorce. However, if able to pass through this phase then like a boat will be strong to face big waves. Household issues are very much both kind, variety and the amount. So it takes cohesiveness of partner in facing and resolving it.

Both likes and dislikes, divorce is a fact that occurs between couples, due to differences in principles that can not be united again in family life. Each remains standing, desire and own will, without being open to succumbing to achieve the unity of the family. The unwillingness and inability to print shortcomings of oneself and / or others, causes a trivial problem to become great, so breaking up with a divorce (Dariyo, 2004). In addition, Sudarto and Wirawan (2001) stated the existence of several factors causing divorce: a) verbal violence, b) economic problems or violence, c) gambling deeds, d) acts in relation to liquor, e) adultery.

South Sulawesi divorce data from January to April 2016 is 10,843 cases. Based on the ranking, 5 districts with high divorce rates are: Makassar (1.812), Wajo (892), and Pinrang (807). (Source: Morning newspaper Wednesday October 12, 2016). Meanwhile, data in the Gowa district religious court showed that for 8 months there were 881 divorce cases with 518 divorce and 170 divorce divorces.

Based on the above data shows that in addition to increasing divorce every year, also seen the number of divorce lawsuit more than the divorce talak. This means more women who feel uncomfortable again with her marriage and do divorce lawsuit. The number of divorces many experienced by young couples, this is because of which is the lack of adjustment between two married people. If this adjustment is fragile it will be very difficult to continue with the household in which there are children who can also become conflicting issues again.

In addition, the researchers obtained data that the process of divorce by wife with the marriage age 20 years and above quite a lot. This condition is very apprehensive because it refers to the above theory, the marriage adjustment proceeds so that the longer it should be more able to understand each other. Divorce with the marriage age of 20 years and above can be described, how the wife has been very familiar with the personality and character of husband, and vice versa. Children's condition has grown teenagers and even adults, so it is not busy anymore take care of household needs. Precisely the wife and husband will more often stay together at home, romantic conditions will happen again.

The relationship of husband and wife provides the foundation and determines the color for the whole relationship in the family. Many families fall apart when there is a failure in a husband and wife relationship. The key to permanent marriage is the success of making adjustments between couples. This adjustment is dynamic and requires a flexible attitude and way of thinking. Adjustment is a continuous interaction with oneself, others, and the environment (Calhoun \& acocella, in Lestari S, 2012).

Thus, if the age of marriage increases, the stronger the marriage bond. This is because these two people know each other's partner so as to make a good adjustment. But if the couple is experiencing many problems or difficulty in adjustment, then it is very likely will happen divorce. Even two people who previously longed to get married, when the problem of adjustments that is never completed and become more complex then the effort to stay away from couples and divorce is inevitable. Waluya (2007) argued that divorce is a loss of harmony that resulted in the husband and wife no longer able to maintain the integrity of the household.

The research results Dewi, EMP. and Basti (2008) found that the intensity of marital conflicts would be higher in wives living with husbands than long-distance relationship (LDRs). The form of resolving conflicts of wives do a lot of quiet action or avoid couples in case of conflict in the household. This happens to couples who live together or who do not live together / far apart (LDR). Thus, the woman / wife has a unique and interesting to be explored further about its psychological dynamics, how they can survive and remain silent until the age of 20 years of marriage and finally dare to commit divorce.

Preliminary study results conducted by researchers in February 2016 with these six 
subjects is that the wives are no longer able to survive the behavior of husbands because Domestic Violence (KDRT) often occurs. The question is why does this occur when it's been in its 20th anniversary, will not this habit be seen when early in the marriage? Another subject explains dare to sue for husband divorce because after studying religion well, her husband is considered not to be a good priest for her and family. Thus, this phenomenon is very interesting to be examined more deeply.

\section{METHOD}

This research uses qualitative research methods, so the data collection is observation, in-depth interview and documentation (such as marriage certificate, divorce letter, family photo). In this study that will be subjected are the wives who have been married for 20 years and above and have children. The approach used is a snow ball sampling technique (Creswell, J.W. 2012) that starts from one person to increase based on information obtained until data is declared saturated or the same hold, no new information. Informants or people who provide this information more and more based on the needs of field analysis. Research activities will stop when the data is sufficient. The description of research subjects as follows:

Table 1. List of Research subjects

\begin{tabular}{cccccc}
\hline No & Subject & Age & Marriage age & $\begin{array}{c}\text { Number of } \\
\text { children }\end{array}$ & $\begin{array}{c}\text { Former husband } \\
\text { job }\end{array}$ \\
\hline 1 & SJ & $\begin{array}{c}46 \text { years } \\
\text { old }\end{array}$ & 21 th & 4 & Contractor \\
\hline 2 & Sy & $\begin{array}{c}46 \text { years } \\
\text { old }\end{array}$ & 25 th & 5 & Contractor \\
\hline 3 & CH & $\begin{array}{c}56 \text { years } \\
\text { old }\end{array}$ & 24 th & 5 & Civil Servant \\
\hline 4 & Sr & $\begin{array}{c}45 \text { years } \\
\text { old }\end{array}$ & 20th & 2 & Sailor \\
\hline
\end{tabular}

Data were analyzed by data reduction step, data presentation and verification. Researcher also performed data validity that is Credibility (Degree of trust), Conducting peer debriefing (discussion), Triangulation (check and recheck). Therefore, additional informants were neighbors and close friends of the subjects, LBH volunteers who assisted the subjects, and head of religious courts as data triangulation.

\section{RESULT AND DISCUSSION}

In this section the researcher will discuss the findings of the field by coding the data of the existing interview (conversation) in accordance with the existing problem formulation and analyzed by the theory.

\section{The picture of marital life}

The Bugis community of Makassar, in choosing a spouse, still tends to seek out existing family ties (eg cousins). This is with consideration to be lasting because it is still close family so it is unlikely to be in conflict until peak. But in reality this study shows that 2 subjects who is in cousin relationship still can divorce. The marital life of these subjects indicates the existence of domestic violence, the displeasing attitude of husbands (too dominant and angry). There are 2 subjects in this study whose children agree if her mother did a divorce. But there are 2 more subjects that children disagree because they feel that their father is good and always giving attention (feeding) the children. But the decision of the wife can not be changed anymore so they remain strong to conduct divorce with or without supporting of their children. The phenomenon of divorce will start from the journey of marriage life because divorce is a staggering and unstoppable event. Freud (Stewart \& Brentano, 2006) explains that divorce is the end result of conflict inherent in the relationship between husband and wife.

\section{The reasons subjects to do divorce}

Main reason for divorce 
Amato (2000) explains that divorce is a formal marriage breakup followed by the freedom to disobey rights and duties as husband and wife. Similarly, who participated in the subjects of this study. The reason for subject 1 is that the husband often commits domestic violence, because he is depressed, taruma and physical injury. Meanwhile, the reason for subject 2 is that the husband has been following a particular stream of fanatics and his role is not to hold HP, There is no TV at home, forbidden to interact with the neighbors as well as letting alone going to mall because it is considered immoral. The term she uses is that even if my house is like a palace, I feel jailed. The statement of subject 3 feels uncomfortable with a husband whose behavior disparages her, disrespects and often speaks : "I divorce you" that occurred since the beginning of marriage. The main reason of subject 4 is due to an affair. For this subject conducting divorce is more honorable than divorced by husband. If a divorce allegation signifies the wife who feels uncomfortable and asks for a divorce. So the subjects looked for information to do divorce lawsuit.

For the beginning of other relationships, marital relationships provide a foundation and determine the colors for family relationships. Many families fall apart by chance in a husband and wife relationship. The key to permanent marriage is the achievement of making adjustments between couples. This adjustment is dynamic and requires a flexible attitude and way of thinking. Adjustment is a continuous interaction with oneself, others, and the environment (Calhoun \& acocella, in Lestasri S, 2012). Broude (Santrock 2002) states the wife's beatings are most prevalent in a society full of aggressive behavior, strict sexual practices, inferior female status, and the use of physical force to resolve disputes.

Jassie Bernard, a sociologist from Pennsylvania State University, noted in his book The Future of marriage that a woman who is capable enough to help and nurture herself before, becomes helpless after 15 or 20 years of marriage. Girls are raised to accept themselves dependent, leaning on the great power that men have. So these women enter marriage with confidence that hope will be fulfilled (Dawling Colette, 1992).

Subject considerations to persist until the age of marriage 20 years
Enduring subjects until the age of marriage 20, one of which is because the children are still small so it still requires a fee. While family income only from husband. The third subject states "If I work (earning) from the first I divorce my husband. Another subject stated that she hoped that with the passage of time, her husband would turn out to be good but apparently it would not, so that she was tired of the conflicts, anxiety and physical as well as psychological exhaustion so as to conduct divorce. This fatigue is because of the husband when he got angry that was very painful but still the wife must serve him to the needs of sex even though it is not sincere do it. This condition makes it despite high conflict but also many children. This is reinforced by the Gowa religious court declaration which states that the woman is very strong in facing sadness and suffering so as to be able to survive for 20 years in the condition of discomfort.

\section{Condition after divorce}

Divorce that occurs will leave quite a lot of problems ranging from relationships with the former and some positive and negative impacts both with regard to their children and with a partner. With the occurrence of divorce so many wives who have to face a continuous struggle with ex-spouses who neglect child support (Kitson \& Morgan, 1990). People reactions to divorce vary greatly, with speed and adjustment rates depending on the resources and circumstances of post-divorce. Amato (2012) showed that most studies had found adults that divorced experiencing more problems in mental and physical health than adults who had married.

Husband in general will change after the divorce, there is a better (not angry) because we rarely met and still provide a living despite what is available. But there is also who took all his properties and no longer support his wife while his children living with her. Children and wives become more calm because there is no more conflict every day. As wives must begin to be independent by struggling for a living to meet their needs and children. Often these wives become sensitive to the neighbor's talk of divorce. However, all subjects expressed more time to be able to deepen religion and worship.

This condition contradicts to Amato's (2000) research finds that children with divorced parents experience more problems in their 
mental and physical health with children who are parent intact. In the result of this study shows wives and children feel happier after divorce because there will be no more violence and conflict between father and mother

\section{Chart 5. Result Discussion}

\begin{tabular}{|c|c|}
\hline $\begin{array}{l}\text { Marriage life : } \\
\text { - Initially quite harmonious, } \\
\text { the husband is responsible } \\
\text { - Wife who obeys to } \\
\text { husband, busy taking care } \\
\text { of husband's business } \\
\text { - Domestic violence occurs } \\
\text { - Surviving for hopes of } \\
\text { change over time }\end{array}$ & $\begin{array}{l}\text { Main considerations to divorce : } \\
\text { - Can not stand the behavior of husband } \\
\text { (Domestic violence) } \\
\text { - Nevertheless like the palace but it feels } \\
\text { like a prison } \\
\text { - Grumpy husbands, children \& family } \\
\text { wives are afraid, disrespectful. } \\
\text { - Feeling betrayed is very hurtful because } \\
\text { the husband is her cousin }\end{array}$ \\
\hline $\begin{array}{l}\text { Divorce impacts : } \\
\text { - More calm as the intensity } \\
\text { of the conflict drops } \\
\text { dramatically } \\
\text { Having plenty of time for } \\
\text { - Self } \\
\text { - } \\
\text { Must earn a living to } \\
\text { supplement their needs }\end{array}$ & $\begin{array}{l}\text { The meaning of divorce age 20th : } \\
\text { - Feeling tired psychically and } \\
\text { physically facing husband } \\
\text { - There is no hope of a husband to } \\
\text { change } \\
\text { - } \quad \text { Children have already grown up } \\
\text { - Relative cost of living can be } \\
\text { - } \begin{array}{l}\text { sought } \\
\text { More time for self }\end{array}\end{array}$ \\
\hline
\end{tabular}

Some conclusions from this research are :

Subject marriage picture

Every marriage life has an unique story and dynamics. This study confirms that the relationship between husband and wife family (cousin) or non family can provide the same dynamics in marriage that is: massive conflict, domestic violence and also adultery. Frequent conflicts and lack of problem-solving capabilities make complex problems at hand. The attitude of the child supporting or not supporting has no effect on the decision of the subject to divorce.

Divorce reason at the age of marriage 20 years

The reason for divorce at the age of 20 years of marriage, is not a single reason. Quite a lot of unpleasant incidents in a husband and wife relationship during wading through housewarming. But because of the tiredness of mind to survive, while there are no signs of positive change from the husband, the children are already big (if the marriage age has reached 20 years), economically ex husband and family are quite helpful and the subjects feel their own life will be more Well then the subject decided to divorce. The perception of the wife, it is honorable to conduct divorce than being divorce.

\section{Life after divorce}

The subjects felt more at ease because the intensity of the conflict dropped dramatically after the divorce because it was no longer home with a husband. The subject has a lot of time for self and the use of deepening religion and worship. Only in this way subject can be grateful and unrepentant with her past life. Nevertheless, subjects should earn extra income even if subsidized by a former husband. In social interaction, subjects often become 
sensitive to the talk of their neighbors or associations discussing divorce.

\section{SUGGESTIONS}

For research subject. Tetap semangat dalam memperbaiki kualitas diri, dengan fokus kebersamaan dengan anak-anak agar hidup yang dijalani terus bermakna. Sharing dengan temanteman yang senasib agar saling memotivasi dan mengisi. Keep the spirit in improving the quality of self, with the focus of togetherness with the children in order life walking on is continually meaningful. Sharing with friends in the same boat to motivate and fill each other. For family. Subjects need social support, therefore it is expected the family understand the condition by providing moral and material assistance. For the Office of Religious Affairs $(K U A)$. Before couples get married, should be given a course on how to build a strong household.

\section{REFERENCES}

Amato, P. R. (2000). The concequences of divorce for adults and children. Journal of marriage and family, Vol. 62, hal. 1269-1287. DOI: $10.1111 / \mathrm{J} .1741-$ 3737.2000.01269.x.

Amato, P. R., \& Previti, D. (2003). People's reasons for divorcing: Gender, social class, the life course and adjustment. Journal of family issues, Vol. 25(5), hal. 602-626.

DOI:

$10.1177 / 0192512 X 03254507$.

Amato,P.R.(2012). The Concequences Of Divorce For Adults And Children: An Update.Journal of marriage and family, Vol. 23, hal. 5-24. DOI: doi:10.5559/di.23.1.01.

Dariyo,A. (2004). Memahami Psikologi Perceraian Dalam Keluarga. Jurnal Psikologi Vol. 2 No. 2.

Davidoff,LL. (1998) Introduction to Psychology, terjemahan Mari Juniati, Jakarta: Erlangga

Dawling C. (1992) Tantangan Wanita Modern Ketakutan Wanuta Untuk Mandiri. Jakarta: Erlangga.
Desmita (2006). Psikologi Perkembangan. Bandung: PT Remaja Rosdakarya

Dewi,EMP dan Basti. (2008). Konflik Perkawinan dan Model Penyelesaian Konflik Pada Pasangan Suami Istri . Jurnal on line, Psikologi Gunadarma Jakarta Vol 2, Nomor 1

Hawkins, A. J., Fackrell, T. A., \& Harris, S. M. (2013). Should I keep trying to work it out? A guidebook for individuals and couples at the crossroads of divorce 9and before). (Online). http://divorce.usu.edu/files/uploads/Sho uldIKeep TryingtoWorkItOut.pdf , diakses tanggal 9 Februari 2016.

Konoras,A.\&Sarkol,P.(2014). Telaah Tingginya Perceraian Di Sulawesi Utara (Studi Kasus Putusan Pengadilan Agama). Jurnal LPPM Bidang EkoSosBudKum, Volume 1 Nomor 1.

Laswell, M., \& Laswell, T. (1987). Marriage and the family, $2^{\text {nd }}$ edition. USA: Wadsworth, Inc.

Lestari,S. (2012). Psikologi keluarga. Jakarta: Kencana Prenada Media Group

Wallerstein, J. S., \& Kelly, J. B. (1996). Surviving the breakup: How children and parents cope with divorce. New York: Basic Books.

Waluya, B. (2007). Sosiologi: Menyelami fenomena sosial di masyarakat. Bandung: PT. Setia Purna Invens.

Papalia D.E, Old SW, Feldman RD. (2008). Human Development. Terjemahan A.K. Anwar. Edisi 9. Jakarta: Kencana

Santrock JW. (1995). Life Span Development terjemahan Ahmad Chusairi. Jakarta: Penerbit Erlangga

Stewart, A. C., \& Brentano, C. (2006). Divorce: Causes and concequences. USA: Yale Univercity Press. 
Sudarto, Lusiana \& Wirawan, Henny E, "Penghayatan makna hidup perempuan bercerai", Jurnal llmiah Psikologi Arkhe (o), 2, ha1.41-57, 2001

Surbakti, E. B. (2008). Sudah siapkah menikah? Panduan bagi siapa saja yang sedang dalam proses menentukan hal penting dalam hidup. Jakarta: PT Elex Media Komputindo.

http://www.readcube.com/articles/10.1111\%2Fj. $1741-$

3737.2000.01269.x?r3 referer=wol\&tra cking_action=preview_click\&show_che ckout $=1 \&$ purchase referrer $=$ onlinelibra ry.wiley.com\&purchase_site_license=LI CENSE DENIED (the consequence of divorce) diakses tanggal 9 februari 2016

https://play.google.com/books/reader?id=0WtV M7-

CRc4C\&printsec $=$ frontcover\&output=re ader\&hl=en\&pg=GBS.PR5 (growing up with divorce)diakses tanggal 9 februari 2016

https://books.google.co.id/books?id=0j9ZAwA AQBAJ\&pg=PA102\&dq=divorce \&hl=e n\&sa $=X \& v e d=0 a h U K E w i r k 6 X j r O f K A$ hXPc44KHU7ZDOcQ6AEIRjAH\#v=on epage $\& \mathrm{q}=$ divorce $\& \mathrm{f}=$ false (divorce: causes and consequences) diakses tanggal 10 februari 2016

http://divorce.usu.edu/files/uploads/ShouldIKee pTryingtoWorkItOut.pdf (syud i try to work it out) diakses tanggal 9 Februari 2016

https://books.google.co.id/books?id=pGxmsW9 Emc0C\&pg=PA41\&dq=perceraian+ada lah\&hl=en\&sa=X\&ved=0ahUKEwjr3 j n0efKAhXMCo4KHX37C8kQ6AEINz AE\#v=onepage $\& \mathrm{q}=$ perceraian $\% 20$ adala $\underline{\mathrm{h} \& \mathrm{f}=\mathrm{false}}$ (sosiologi: menyelami fenomena sosial di masyarakat) diakses tanggal 10 Februari 2016 